\title{
Front Matter: Volume 11857
}

, "Front Matter: Volume 11857," Proc. SPIE 11857, Remote Sensing of the Ocean, Sea Ice, Coastal Waters, and Large Water Regions 2021, 1185701 (15 October 2021); doi: 10.1117/12.2615056

SPIE. Event: SPIE Remote Sensing, 2021, Online Only 


\title{
PROCEEDINGS OF SPIE
}

\section{Remote Sensing of the Ocean, Sea Ice, Coastal Waters, and Large Water Regions 2021}

\author{
Charles R. Bostater J r. \\ Xavier Neyt \\ Editors
}

\section{3-17 September 2021 \\ Online Only, Spain}

Sponsored by

SPIE

Cooperating Organisations

European Optical Society

EARSeL-European Association of Remote Sensing Laboratories (Gemany)

ISPRS - Intemational Society for Photogra mmetry and Remote Sensing

CENSIS (United Kingdom)

SEDOPTICA

Supporting Organisation

INEUSTAR/INDUCIENCIA

Published by

SPIE 
The papers in this volume were part of the technical conference cited on the cover and title page. Papers were selected and subject to review by the editors and conference program committee. Some conference presentations may not be available for publication. Additional papers and presentation recordings may be available online in the SPIE Digital Library at SPIEDigitalLibrary.org.

The papers reflect the work and thoughts of the authors and are published herein as submitted. The publisher is not responsible for the validity of the information or for any outcomes resulting from reliance thereon.

Please use the following format to cite material from these proceedings:

Author(s), "Title of Paper," in Remote Sensing of the Ocean, Sea Ice, Coastal Waters, and Large Water Regions 2021, edited by Charles R. Bostater Jr., Xavier Neyt, Proc. of SPIE 11857, Seven-digit Article CID Number (DD/MM/YYYY); (DOI URL).

ISSN: 0277-786X

ISSN: 1996-756X (electronic)

ISBN: 9781510645585

ISBN: 9781510645592 (electronic)

Published by

SPIE

P.O. Box 10, Bellingham, Washington 98227-0010 USA

Telephone +1 3606763290 (Pacific Time)

SPIE.org

Copyright @ 2021 Society of Photo-Optical Instrumentation Engineers (SPIE).

Copying of material in this book for internal or personal use, or for the internal or personal use of specific clients, beyond the fair use provisions granted by the U.S. Copyright Law is authorized by SPIE subject to payment of fees. To obtain permission to use and share articles in this volume, visit Copyright Clearance Center at copyright.com. Other copying for republication, resale, advertising or promotion, or any form of systematic or multiple reproduction of any material in this book is prohibited except with permission in writing from the publisher.

Printed in the United States of America by Curran Associates, Inc., under license from SPIE.

Publication of record for individual papers is online in the SPIE Digital Library.

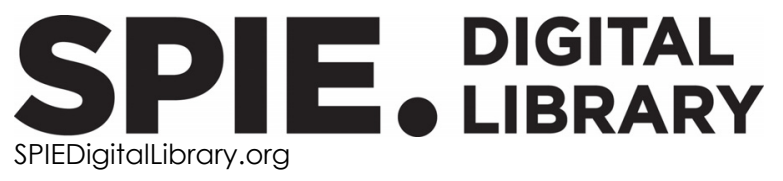

Paper Numbering: A unique citation identifier (CID) number is assigned to each article in the Proceedings of SPIE at the time of publication. Utilization of CIDs allows articles to be fully citable as soon as they are published online, and connects the same identifier to all online and print versions of the publication. SPIE uses a seven-digit CID article numbering system structured as follows:

- The first five digits correspond to the SPIE volume number.

- The last two digits indicate publication order within the volume using a Base 36 numbering system employing both numerals and letters. These two-number sets start with $00,01,02,03,04$, 05, 06, 07, 08, 09, 0A, OB ... 0Z, followed by 10-1Z, 20-2Z, etc. The CID Number appears on each page of the manuscript. 


\section{Contents}

BATHYMETRY, SHAWOW WATERS AND SUSPENDED SEDIMENTS

1185702 Case study of UAS videography for depth inversion within a shallow water surf zone along the Texas Gulf Coast (Invited Paper) [11857-1]

1185703 Satellite-derived bathymetry for shallow coastal waters in Cyprus [11857-2]

1185705 Remote sensing of suspended partic ulate matter: case studies of the Sulak (Caspian Sea) and the Mzymta (Black Sea) mouth areas [11857-4]

OIL, RUORESCENCE AND HYPERSPEC TRALSENSING

1185707 Deep leaming based automatic detection of offshore oil slicks using SAR data and contextual information [11857-6]

1185708 Advancements to Monte-Carlo modeling of the underwater light field using synthetic water surface slopes and synthetic bottom reflectance signatures [11857-7]

WATER QUAUTY AND BIO-OPIICALSENSING AND MODEUNG

1185709 The long-term effect of brine discharge on the Arabian Gulf waters (Invited Paper) [11857-9]

11857 OA Long-tem obsenations of chlorophyll-a concentration in Lake Honghu using multi-source remote sensing data [11857-10]

WATER BOTIOM AND SURFACE WAVE SENSING

$11857 \mathrm{OE} \quad$ On the use of suborbital drone imaging and in-situ calibrations of the water surface for characterization of water waves: a space-time imaging approach (Invited Paper) [11857-14]

\section{SCATIERING AND MULTISPECTRAL SENSING}

$11857 \mathrm{OL} \quad$ A WorldView-3 multispectral glint comection methodology and relation to hyperspectral signatures in space coast Forida waters [11857-21]

11857 OM A study of relation between non-Bragg mic rowave radar backscattering and decimeter-scale wind waves [11857-22] 


\section{POSTER SESSON}

11857 ON Usage of SAR and VIS data for monitoring of the surface oil pollution in the off-shore oilproducing area of the Caspian Sea [11857-23]

1185700 Manifestation of the Oka-Volga confluence zone during the ice melting in radarand optical satellite images [11857-25]

11857 OP Investigation of the possibility of ecological monitoring of inland water resenoirs using an automatic radarsystem [11857-26]

$118570 \mathrm{~A}$ An empinical radar backscatter model at co-polanized and cross-polanized $\mathbf{x}$-band under high-wind conditions [11857-27]

11857 OR Wind stress retrieval in tropical cyclones from collocated GPS-dropsonde data and crosspolarization Sentinel-1 IW mode [11857-28]

11857 OS The multisensory approach to hydrophysical measurements of the ocean surface layer [11857-29]

11857 OU Wave tank modeling of the damping of gravity waves due to ice floes in application to ocean remote sensing [11857-31]

$11857 \mathrm{OV}$ Eastic properties of inhomogeneous surfactant films in application to ocean remote sensing [11857-32] 